\title{
An Approach to Develop and Integrate Existing Curriculum to Theme Based Curriculum Structure for Strengthening Postgraduate Studies in Engineering Education
}

\author{
Vinayak N Kulkarni ${ }^{1}$, V. N. Gaitonde ${ }^{2}$, B. B. Kotturshettar ${ }^{3}$, Jangali Satish G. ${ }^{4}$ \\ ${ }^{1234}$ School of Mechanical Engineering, KLE Technological University, Hubballi, Karnataka, INDIA \\ 1vinayak33me@gmail.com \\ 2 gaitondevn@yahoo.co.in \\ 3 bbkshettar@kletech.ac.in \\ 4jangalisatish@gmail.com
}

\begin{abstract}
In today's higher education system, the concept of specialization plays a vital role in the career development of engineering students across the world. Meanwhile, the requirement for automation engineers in manufacturing sector is increasing continuously due to upgradation of the technology in today's industrial scenario. The methodology of theme based curriculum design and its integration to the existing curriculum along with the assessment pattern have been explained throughout the paper. The results and attainment of performance indicators have been analyzed. It is found that the percentage attainment have improved from initial conventional laboratory experiments to final open-ended experiment of laboratory course leading to active learning among students.
\end{abstract}

Keywords: Postgraduate program; curriculum design; theme based curriculum; program outcome; performance indicators; higher engineering education

Vinayak N Kulkarni

School of Mechanical Engineering, KLE Technological University, Hubballi, Karnataka, Indiavinayak33me@gmail.com

\section{Introduction}

In today's engineering education environment there are thousands of engineering educational institutes offering hundreds of postgraduate (PG) programs across many counties. Higher education, especially, post graduate programs in engineering domains are finding their importance in today's technical education because of various reasons like concept of specialization.

There are many engineering colleges running the institutes under the affiliation of some major universities and are following the curriculum prescribed by the parent university. In such cases the problems encountered during the delivery of the content are more, compared to the institutes having university or autonomous status. Institutes with university or autonomous status have the freedom and flexibility to design their own curriculum based on requirement of the industries and society. Many institutes are offering the postgraduate engineering programs to the students in a very traditional approach, which is not having much impact on the skill and knowledge development of the budding engineers. Although there are many pedagogical changes, new practices in engineering education, most of them are implemented at the undergraduate (UG) level. Postgraduate engineering programs are the one which should offer a high level of specialized programs for the aspirant engineering graduates. Curriculum design as per industrial requirement is a 
real challenge to leading higher engineering education institutes. There are many educational institutes practicing outcome based education policies for both UG and PG programs around the world. But in Indian context the outcome based education policies are to be still introduced to many engineering educational institutes. It has been a very common practice in India that the curriculum for PG program is set at a little higher level than that of UG level. Many institutes who follow engineering education principles and outcome based education policies are also on the same line. But, in reality it's the depth and focus of the content that matters for a PG program to be called as a specialization.

Some educational institutes and researchers have tried to develop new techniques and strategies to improve PG program courses and curriculum across the world. Dickie and Jay (2010) developed a hybrid approach concept where it motivates students to be a self motivated and self learner which maximizes the students learning capabilities and skills by the means of action research strategies and problem based learning. M.J Servan et al. (2009) have worked on problem based learning and action research in $\mathrm{PG}$ teaching where the method of online teaching model was developed to enhance the educational practice of the students. Kulkarni et al (2016) have designed the course project content delivery for PG programs in an innovative way where the focus is more on measuring the performance indicators of outcome based education. Tobbell et al. (2009) has explored more on transition to post graduate study which basically highlighted the shifting identities in interaction with communities, practice and participation. Dodge (1995); Schweinhart \& Weikart (1998) have discussed the idea of creating age appropriate curriculum and its effects it may have later in child's life. Melear and Lunsford (2007) created a theme-based unit on earthworms to demonstrate how a long-term activity could attend to the various content afforded by the National Science Education standards. Lonning, Defranco, and Weinland (1998) have defined theme-based curriculum as "both a focus and organizing framework that guide the development and implementation of a cohesive, interrelated series of lessons or activities". In addition, many researchers are interested in creating new models of teaching in which to test their hypothesis, in hopes of reforming the practices that they feel are not "teaching" students how to apply what they learn to real life situations. Halimah and Nurfadillah (2018) found the improvement of students' achievement in narrative text by using Theme Based Teaching Approach. Berry \& Mindes (1993) discuss about incorporating an intriguing theme into the curriculum and enhance the learning process for children. Similarly, there are many researchers working on different educational objectives in higher engineering education program. After going through the different engineering educational strategies or exploration in engineering education research by different researchers, it can be observed that the curriculum changes and new practices in post graduate curriculum design is not much explored. Therefore an attempt has been made by the School of Mechanical Engineering Production Management Post Graduate Program to introduce a theme based curriculum design for first year Master of Technology (M.Tech) in Production Management course.

\section{Theme Based Curriculum Design}

The basic motivation for upgrading the existing traditional curriculum structure of PG program to theme based curriculum structure is that the employability rate of the engineering graduates is becoming low and low every year due to lesser specialized knowledge and skill level of the students as per today's industrial needs and requirement. Basically, the postgraduate program or Master Programs has to offer students a kind of curriculum which makes student more confident in their elected domains and should improve the skill set along with the knowledge. The courses offered should be more of job oriented in nature. The new theme based curriculum design is more focused on making students more skillful and content based as per today's industrial requirement and societal needs. The basic idea of introducing this theme based curriculum at the first semester level of PG program is to provide a new type of learning environment to students where in they are exposed to theory, laboratory and project work assignment revolving around a common theme. All the courses that are the part of theme based design will be delivered in a concurrent approach with almost same context and in a holistic way. These courses should be capable of associating to the real life examples and real industrial case studies for easy and deeper understanding of the concepts to the learners. Theme based curriculum design, delivery and their assessments is a challenging but at the same time a very useful and productive activity for both teachers and learners. Therefore, the paper explains the details 
about the methodology adopted and implemented for designing and integrating theme based curriculum design into the existing curriculum structure, delivery methods as per the curriculum changes, experiences, advantages and outcomes of theme based curriculum design.

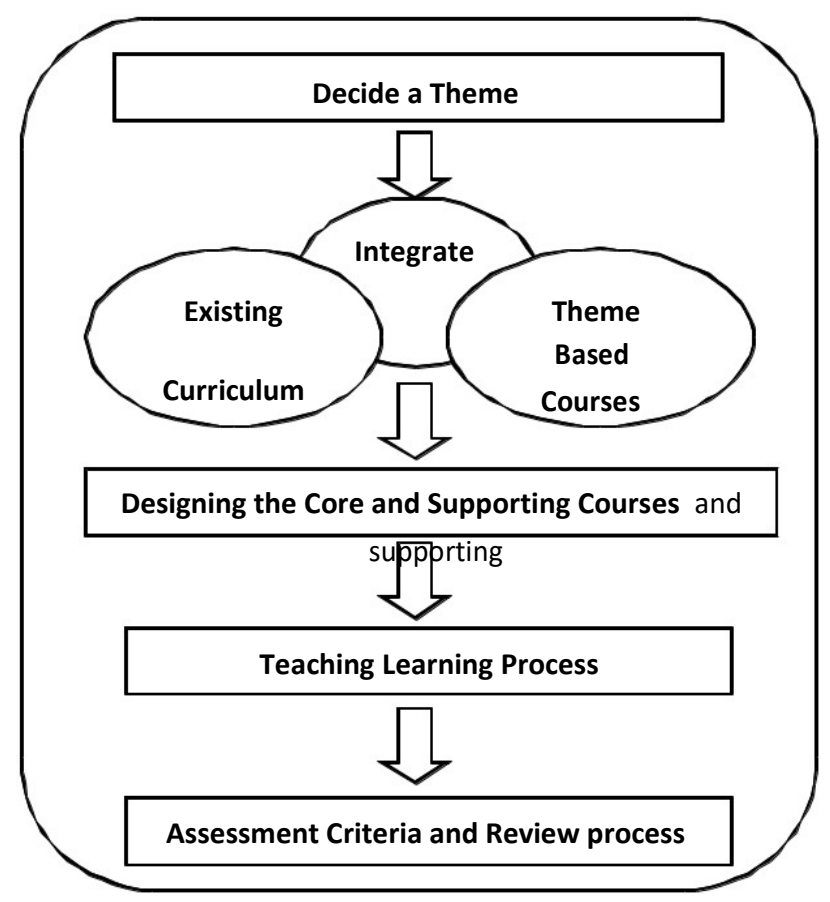

Fig. 1 : Theoretical framework for theme based curriculum design

\section{Methodology}

The motivation for developing the framework for theme based curriculum design is the steps of thematic learning instruction. Thematic learning is a pedagogical model based on the selection of a theme or topic of study. Similarly, the thematic approach can be decided, modified and integrated based on the postgraduate course requirement. Figure 1 explains the methodology developed and adopted for the theme based curriculum design.

\section{A. Decide a theme}

Deciding the theme for theme based curriculum design is the first and most time consuming phase of the process. Themes for the post graduate program can be decided on various factors. The current demand for the particular type of skill set in the industry is one of the important deciding factors in this process. The educational institutes or the personnel involved in designing the course can do a detailed literature survey and have an initial brainstorming sessions with the other stakeholders like staff members, program coordinator and head of the department. After the brainstorming session and initial discussions within these members a detailed meeting can be arranged with the industry personnel to decide upon the suitability of the new theme to the existing and upcoming industries. As the theme was to be decided for production management postgraduate course of mechanical engineering department, after undergoing the above mentioned procedure in this phase, the broad areas selected in for theme based approach were manufacturing technology, manufacturing simulation, manufacturing management and manufacturing automation. Then after the discussions with few automation industries, detail analysis of the Indian industrial scenario and their requirements, also keeping in mind Industry 4.0 and make in India initiatives by Indian Prime Minister, the theme of "Manufacturing Automation" was finalized for the academic year 2017-18. The job opportunities in the field of manufacturing automation were also considered during the selection of theme for the production management program.

B. Integration of identified theme with existing curriculum

In the second stage integration of the identified theme with the existing curriculum has to happen without affecting the structure of the existing curriculum. In this process the credits of the existing curriculum and credits to be offered for the identified theme has to be studied and matched carefully. The integration process should add value to the existing curricula and the existing curricula should be strengthened in terms of academic contents. In the present study one core course along with one main laboratory course were identified for the manufacturing automation theme and the mini project and industrial seminar were also correlated with the selected theme of manufacturing automation as supporting courses. Some courses which were not adding any value to the skill set of the students were deleted from the existing curriculum and these theme based courses were introduced in their place.

\section{Designing the core and supporting courses}

The third important step in this methodology is to design the core and supporting courses of the 


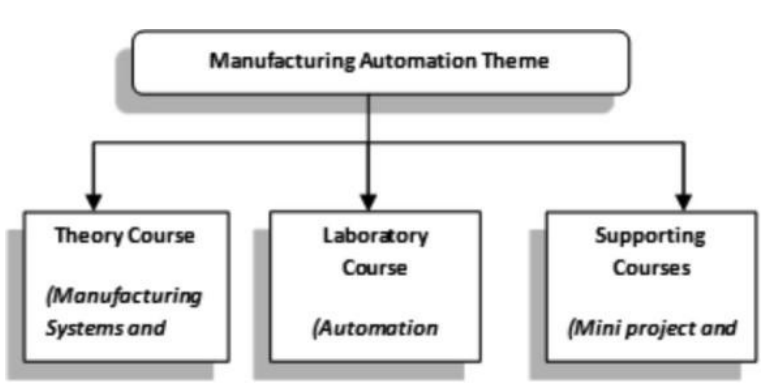

Fig.2 : Courses under theme based curriculum

identified theme in a detailed manner. The contents to be introduced inside the core courses and supportive courses along with the method of delivery and assessment criteria are to be identified and finalized during this process. Figure 2 shows the different courses identified under manufacturing automation theme for production management PG program.

The theory course selected under the theme of manufacturing automation was manufacturing systems and automation which basically covers all the theoretical aspects of manufacturing systems in industry and automation of the same. The contents of the theory course will be discussed during further sections of the paper. The theory course was designed for 3 credits with 40 hours of syllabus content. The syllabus was designed to deliver the contents in the form of class room delivery, case study approach, seminars and assignment. The evaluation of the students was through two minor exams of 20 marks each, followed by assignment assessment of 10 marks. Totally the continuous internal assessment was done for 50 marks. The students will go through the insemester assessment (ISA) of 50 marks separately. Therefore a student will be evaluated for a total of 100 marks inclusive of minor exams, assignments and end semester assessment (ESA).

Automation lab was designed as a part of manufacturing automation theme activity. The lab was designed in such a way that it is complete synchronized with theory course content. Further the conduct of laboratory was divided into four parts namely demonstration, exercises, structured enquiry and open ended experiments [10]. All the exercises in these formats were assessed throughout the semester in a continuous evaluation basis as a part of ISA for 80 marks. Remaining 20 marks were evaluated as a part of ESA.

There were two supporting courses designed to support the main theory and laboratory courses. One of the supporting courses was mini project of 3 credits to give a complete exposure of working of automation projects and the other was arrangement of industrial technical guest talk of 1 credit which again was arranged to give the real time examples of automation from industrial personnel regarding the latest trends in automation technology. The main intention of introducing mini project at the first year level is to make students familiar with project aspects and develop skills in the identified area. There were three reviews throughout the mini project course to measure the performance of the students. Each team of project batch consisted of two students and one guide to monitor the progress of the work. The broad topic for the mini project was given as Internet of Things (IOT) based automation projects. On the other end, staff members of the department were in constant interaction with International Society of Automation for arrangement of guest lecture. The guest lecture was delivered by an Industrial Personnel from International Society of Automation on latest trends in industrial automation technology. Further students were evaluated on industrial talk through assignments and seminars.

\section{Teaching learning process}

Once the main courses and supporting courses are designed then the main process is to undergo teaching learning process. To keep the courses always synchronized and to deliver the theory and laboratory courses hand in hand, these automation theme based courses were handled and monitored by the same faculty. There is always a benefit in the teaching learning process when the related courses are delivered, handled and monitored by a single faculty in charge. Of course there were few instructors and other subordinates to support the laboratory, mini project and industrial technical talk activities, but overall process was monitored and driven by a single in charge faculty. 60 percentage of the theory course was planned to deliver in a traditional class room teaching learning process using blackboard and power point presentations. 30 percentage of the teaching learning process was through case study solving and group discussion method and the remaining 10 percentage was through assignment and self study component approach. In laboratory courses the teaching learning process is completely through hands on approach. All the experiments were planned to give the hands on exposure and develop the automation skills for the students. It was a unique teaching learning experience in conducting automation based 
mini project course. The course is designed to be student centric, where students work in a team right from project conceptualization phase to project completion phase on their own with some assistance through laboratory instructors and under the guidance of allotted guide member. Students were exposed to new automation technology wherever required every week through the special classes planned for mini project assistance. Therefore, it is distinctiveness in teaching learning methodology of theme based curriculum delivery that makes it unique and effective compared to traditional approaches.

\section{E. Assessment criteria and Review}

Assessment criteria and review process is a last and important phase of theme based curriculum design activity. Every activity or process is incomplete without proper assessment and there will be no improvements if review process is not carried out. Therefore assessment and review process is given a lot of importance and care in this design process. All the courses in this theme based approach are measured and assessed through ISA and ESA process whether it is a core course or supporting course. There are many graduate attributes defined by the National board of accreditation (NBA) for the post graduate program in India and University has identified specific program outcomes based on these graduate attributes defined by NBA. Appropriate program outcomes and performance indicators are identified for all the courses of theme based curriculum design which will be mentioned in section 3. All the performance indicators are measured through appropriate rubrics based assessment. The theory course was assessed through minor exam, major exam and assignment process whereas laboratory course and mini project are assessed through appropriate review process using proper rubrics. Rubrics based assessment is always a fair assessment criteria in any education system as it basically distinguishes the grades and marks of the students based on their performance. Review of the content delivery and effectiveness of the process will be measured through regular departmental meetings, class committee meetings and through formative and summative feedback process. Appropriate measures will be taken as and when needed based on the review process to keep the synchronization between all the courses in theme based design.

\section{Case Study on Implementation of Theme Based Curriculum}

As mentioned in the earlier sections of the paper, this theme based curriculum was designed for 1st semester M.Tech in Production Management students of Mechanical Engineering discipline. There was a challenge to deliver the course content of theory and laboratory to these students as automation based theme required the pre-requisite of knowledge of mechatronics, control engineering and programming from the student's point of view. Unfortunately, $50 \%$ of the students did not study either mechatronics or control engineering in their undergraduate curriculum designed by their universities. Similarly, these students were not exposed to programming concepts during their bachelor degree. Therefore, these issues were also kept in mind during the design of theme based curriculum and accordingly the contents were designed, modified and delivered to the students. Further this case study will explain about the gradate attributes, program outcomes, competencies and related performance indicators (PIs), integration of theory and laboratory courses, mini project theme and review process, conduct of laboratory and its assessment will be the highlight of this case study section as it can give a clear idea about the conduct of the experiments in a systematic manner.

The table 1 shows the Program Outcomes defined for the Production Management PG program and are aligned with the Graduate Attributes defined by NBA.

For graduate attribute, appropriate competencies and related performance indicators have been defined. In theme based curriculum delivery for all the courses executed under manufacturing automation theme are assessed through appropriate performance indicators. As a sample the competencies and related PIs of Automation laboratory course is mentioned in table 2.

All the experiments or exercises in the theme based curriculum are assessed and evaluated through fair rubrics based assessment system. Once the competencies and performance indicators are defined as shown in table 2, and then rubrics are framed based on the type of exercise to be assessed. Every experiment and activity is assessed through rubrics. A sample of Automation laboratory course rubrics are mentioned in table 3 .

A. Integration of the courses under theme based curriculum

The theory, laboratory and mini project courses 
have been integrated in such a way that the theory content covered in the class room teaching has to be validated through the laboratory sessions and implemented in the project slots. Table 4 gives the clear idea about the contents of the courses and its co-relation with the theory course outcome.

Table 1 : Graduate attributes with corresponding program outcome

\begin{tabular}{|c|l|l|}
\hline $\begin{array}{c}\text { Sl. } \\
\text { No }\end{array}$ & \multicolumn{1}{|c|}{ Graduate Attribute } & \multicolumn{1}{|c|}{ Program Outcome } \\
\hline 1 & Scholarship of Knowledge & $\begin{array}{l}\text { Ability to apply enhanced knowledge and skills in the areas of manufacturing technology and } \\
\text { automation. }\end{array}$ \\
\hline 2 & Critical Thinking & $\begin{array}{l}\text { Ability to synthesize, analyze and evaluate the information to solve manufacturing technology and } \\
\text { automation related problems. }\end{array}$ \\
\hline 3 & Problem Solving & $\begin{array}{l}\text { Ability to solve manufacturing technology and automation related problems through } \\
\text { conceptualization, analysis and evaluation in the context of public health and safety, cultural, societal } \\
\text { and environmental issues. }\end{array}$ \\
\hline 4 & Research Skill & $\begin{array}{l}\text { Ability to carry out research by identifying the problem, synthesis through literature survey, designing } \\
\text { and conducting the experiments, analyzing and interpreting the results related to manufacturing } \\
\text { technology and automation. }\end{array}$ \\
\hline 5 & Modern ToolUsage & $\begin{array}{l}\text { Ability to use modern tools in modeling, simulation and analysis of manufacturing technology and } \\
\text { automation related problems. }\end{array}$ \\
\hline 6 & $\begin{array}{l}\text { Collaborative and } \\
\text { Multidisciplinary work }\end{array}$ & $\begin{array}{l}\text { Ability to participate effectively in multidisciplinary teams and contribute towards achieving the } \\
\text { common goals of the team. }\end{array}$ \\
\hline 7 & $\begin{array}{l}\text { Project Management and } \\
\text { Finance }\end{array}$ & $\begin{array}{l}\text { Ability to carry out feasibility study and evaluate projects and considering economical and financial } \\
\text { factors. }\end{array}$ \\
\hline 8 & Communication & $\begin{array}{l}\text { Ability to communicate effectively in both oral and written forms with superiors, subordinates, peers } \\
\text { and other stakeholders. }\end{array}$ \\
\hline 9 & Life-long Learning & Ability to engage in life-long learning that will help him/her for growth in their professional career. \\
\hline 10 & $\begin{array}{l}\text { Ethical Practices and } \\
\text { Social Responsibility }\end{array}$ & $\begin{array}{l}\text { Ability to demonstrate his/her understanding of professional and ethical responsibility while assessing } \\
\text { a situation considering the impact of technology from the global, economic, environmental and } \\
\text { societal perspective. }\end{array}$ \\
\hline 11 & $\begin{array}{l}\text { Independent and Reflective } \\
\text { Learning }\end{array}$ & \begin{tabular}{l} 
Ability to critically self examines and assess for self-awareness. \\
\hline
\end{tabular}
\end{tabular}

Table 2 : Competency with performance indicators

\begin{tabular}{|c|c|c|}
\hline Graduate Attributes & Competency & Performance Indicators (PIs) \\
\hline \multirow[t]{4}{*}{ 5. Modern Tool Usage } & \multirow{4}{*}{$\begin{array}{l}\text { 5.1 Possess competence to use the modern } \\
\text { engineering tools of manufacturing } \\
\text { technology/automation to address the } \\
\text { manufacturing related problems. }\end{array}$} & $\begin{array}{l}\text { 5.1.1 Identify different modern engineering tool/ tools in } \\
\text { manufacturing technology and automation fields. }\end{array}$ \\
\hline & & $\begin{array}{l}51.2 \text { Evaluate the tool/tools for appropriateness to address the } \\
\text { identified problem. }\end{array}$ \\
\hline & & $\begin{array}{l}\text { 5.1.3 Select and use the modern tool/tools in } \\
\text { synthesis/analysis, computer simulations for system/process } \\
\text { design, modeling and optimization. }\end{array}$ \\
\hline & & 5.1.4 Discuss the inferences and conclusion. \\
\hline
\end{tabular}

Table 3 : Rubrics to evaluate open ended experiment in laboratory component

\begin{tabular}{|c|c|c|c|c|c|}
\hline \multicolumn{6}{|c|}{ Graduate Attribute 5: Modern tool usage } \\
\hline \multicolumn{6}{|c|}{$\begin{array}{l}\text { Program outcome: Create, select, and apply appropriate techniques, resources, and modern engineering and IT tools including prediction and } \\
\text { modeling to complex engineering activities with an understanding of the limitations. }\end{array}$} \\
\hline \multicolumn{6}{|c|}{$\begin{array}{l}\text { Competency: 5.1 Possess competence to use the modern engineering tools of manufacturing technology/automation to address the } \\
\text { manufacturing related problems }\end{array}$} \\
\hline Performance Indicators (PIs) & $0-2 M A R K S$ & 2-4 MARKS & 4-6 MARKS & 6-8 MARKS & 8-10 MARKS \\
\hline $\begin{array}{l}5.1 .1 \\
\text { Identify different modern } \\
\text { engineering tool/ tools in } \\
\text { manufacturing technology and } \\
\text { automation fields. }\end{array}$ & $\begin{array}{l}\text { Does not answer the } \\
\text { questions related to } \\
\text { modern engineering } \\
\text { tools and has no idea } \\
\text { about alternative } \\
\text { tools and techniques } \\
\text { available in } \\
\text { automation. }\end{array}$ & $\begin{array}{l}\text { Answers less than } 50 \% \\
\text { of the questions asked } \\
\text { related to different } \\
\text { modern engineering } \\
\text { tools and also fails to } \\
\text { list alternative tools and } \\
\text { techniques available. }\end{array}$ & $\begin{array}{l}\text { Answers } 50 \% \text { of the } \\
\text { questions asked } \\
\text { related to modern } \\
\text { tool usage in } \\
\text { industrial } \\
\text { automation and is } \\
\text { not much clear } \\
\text { about the different } \\
\text { tools and techniques } \\
\text { used. }\end{array}$ & $\begin{array}{l}\text { Answers almost } \\
\text { all questions } \\
\text { related to modern } \\
\text { tools used in } \\
\text { automation but not } \\
\text { so sure about the } \\
\text { alternative tools } \\
\text { and techniques. }\end{array}$ & $\begin{array}{l}\text { Answers to all the } \\
\text { questions related } \\
\text { to use of modern } \\
\text { tools for } \\
\text { automation } \\
\text { purpose and is } \\
\text { capable of listing } \\
\text { alternative tools } \\
\text { and techniques for } \\
\text { the same. }\end{array}$ \\
\hline
\end{tabular}




\begin{tabular}{|c|c|c|c|c|c|}
\hline $\begin{array}{l}5.1 .2 \\
\text { Evaluate the tool/tools for } \\
\text { appropriateness to address the } \\
\text { identified problem. }\end{array}$ & $\begin{array}{l}\text { Fails to write the } \\
\text { appropriate program } \\
\text { for the given } \\
\text { problem. Has no idea } \\
\text { about usage of the } \\
\text { appropriate software } \\
\text { or logic required } \\
\text { solving the problem. } \\
\text { Do not possess the } \\
\text { capability of } \\
\text { identifying the errors } \\
\text { in the program or } \\
\text { logic. }\end{array}$ & $\begin{array}{l}\text { Is able to write correct } \\
\text { program /logic/code to } \\
\text { some extent only if } \\
\text { proper help is extended } \\
\text { by the instructor. } \\
\text { Executes the program } \\
\text { after too many } \\
\text { corrections to solve the } \\
\text { given problem. } \\
\text { Has many errors in } \\
\text { programs but is not so } \\
\text { much capable of } \\
\text { identifying the errors if } \\
\text { found. }\end{array}$ & $\begin{array}{l}\text { Is able to write } \\
\text { correct program } \\
\text { /logic/code to some } \\
\text { extent and executes } \\
\text { the program after } \\
\text { many corrections to } \\
\text { solve the given } \\
\text { problem. } \\
\text { Has few errors in } \\
\text { programs but is not } \\
\text { so much capable of } \\
\text { identifying the } \\
\text { errors if found. }\end{array}$ & $\begin{array}{l}\text { Is able to write } \\
\text { correct program } \\
\text { /logic/code and } \\
\text { executes the } \\
\text { program correctly } \\
\text { to solve the given } \\
\text { problem. } \\
\text { Has no errors in } \\
\text { programs but is } \\
\text { not so much } \\
\text { capable of } \\
\text { identifying the } \\
\text { errors if found. }\end{array}$ & $\begin{array}{l}\text { Is able to write } \\
\text { correct program } \\
\text { /logic/code and } \\
\text { executes the } \\
\text { program correctly } \\
\text { to solve the given } \\
\text { problem. } \\
\text { Has no errors in } \\
\text { programs but } \\
\text { capable of } \\
\text { identifying the } \\
\text { errors if found. }\end{array}$ \\
\hline $\begin{array}{l}5.1 .3 \\
\text { Select and use the modern } \\
\text { tool/tools in synthesis/analysis, } \\
\text { computer simulations for } \\
\text { system/process design, modeling } \\
\text { and optimization. }\end{array}$ & $\begin{array}{l}\text { Fails to understand } \\
\text { the need of the } \\
\text { problem and hence } \\
\text { can do not execute } \\
\text { the program nor able } \\
\text { to write related } \\
\text { analysis. Interfacing } \\
\text { concepts are } \\
\text { extremely poor. }\end{array}$ & $\begin{array}{l}\text { Struggles to execute the } \\
\text { programs. Has } \\
\text { difficulty with } \\
\text { interfacing concepts. } \\
\text { Analysis section is poor } \\
\text { and sometimes not } \\
\text { acceptable. }\end{array}$ & $\begin{array}{l}\text { Understands the } \\
\text { problem to some } \\
\text { extent. Resolves to } \\
\text { get proper results. } \\
\text { Interfacing idea is } \\
\text { not upto the mark. } \\
\text { Needs regular } \\
\text { assistance in } \\
\text { interfacing. } \\
\text { Analysis is } \\
\text { acceptable. } \\
\end{array}$ & $\begin{array}{l}\text { Excellent } \\
\text { understanding of } \\
\text { the problem. } \\
\text { Writes an } \\
\text { appropriate } \\
\text { program for the } \\
\text { given situation. } \\
\text { Has good idea } \\
\text { about interfacing. } \\
\text { Analysis is good. }\end{array}$ & $\begin{array}{l}\text { Excellent } \\
\text { understanding of } \\
\text { the problem. } \\
\text { Writes an efficient } \\
\text { program for the } \\
\text { given situation. } \\
\text { Has clear idea } \\
\text { about interfacing. } \\
\text { Analysis is very } \\
\text { good. }\end{array}$ \\
\hline $\begin{array}{l}5.1 .4 \\
\text { Discuss the inferences and } \\
\text { conclusion. }\end{array}$ & $\begin{array}{l}\text { No inference and no } \\
\text { proper conclusion. } \\
\text { Poor conduct of op en } \\
\text { ended experiment. } \\
\text { Has no idea about } \\
\text { how an automation } \\
\text { system makes use of } \\
\text { concepts learnt in } \\
\text { theory and } \\
\text { laboratory. }\end{array}$ & $\begin{array}{l}\text { Inferences drawn from } \\
\text { the conduct and } \\
\text { analysis of the } \\
\text { experiment are not } \\
\text { satisfactory. No proper } \\
\text { information on how to } \\
\text { adapt and use } \\
\text { automation knowledge } \\
\text { of theory and laboratory } \\
\text { courses to an open } \\
\text { ended problem. }\end{array}$ & $\begin{array}{l}\text { Inferences drawn } \\
\text { from the conduct } \\
\text { and analysis of the } \\
\text { experiment are } \\
\text { average. Has not } \\
\text { utilized the } \\
\text { automation theory } \\
\text { and lab knowledge } \\
\text { to solve the open } \\
\text { ended problems. }\end{array}$ & $\begin{array}{l}\text { Is able to draw } \\
\text { appropriate } \\
\text { inferences and } \\
\text { write proper } \\
\text { conclusion. Uses } \\
\text { the automation } \\
\text { knowledge of both } \\
\text { theory and } \\
\text { laboratory to little } \\
\text { extent to solve } \\
\text { open ended } \\
\text { problem. }\end{array}$ & $\begin{array}{l}\text { Is able to draw } \\
\text { appropriate } \\
\text { inferences and } \\
\text { write good } \\
\text { conclusion. Uses } \\
\text { the automation } \\
\text { knowledge of both } \\
\text { theory and } \\
\text { laboratory to full } \\
\text { extent to solve } \\
\text { open ended } \\
\text { problem. }\end{array}$ \\
\hline
\end{tabular}

Table 4: Integration of theory course with laboratory and mini project

\begin{tabular}{|c|c|c|}
\hline Theory Course Outcomes & Laboratory Experiments & Project Review \\
\hline $\begin{array}{l}\text { I. Recognize the role of automation in production } \\
\text { system and manufacturing operations. }\end{array}$ & $\begin{array}{l}\text { 1. Introduction to non controller based } \\
\text { applications } \\
\text { 2. Exercises on non controller based } \\
\text { applications }\end{array}$ & \multirow{2}{*}{$\begin{array}{l}\text { Review } 1 \\
\text { i. Importance and significance of } \\
\text { proposed work, Literature survey, IOT } \\
\text { concept } \\
\text { ii. Problem definition, objectives and } \\
\text { scope }\end{array}$} \\
\hline $\begin{array}{l}\text { II. Select an appropriate industrial control system } \\
\text { for manufacturing systems and industrial } \\
\text { automation. }\end{array}$ & $\begin{array}{l}\text { 3. Controller based applications } \\
\text { 4. Experiments to learn the applications of } \\
\text { sensors, actuators (electrical, hydraulics } \\
\text { and pneumatics)and control system }\end{array}$ & \\
\hline $\begin{array}{l}\text { III. Er } \\
\text { manufa }\end{array}$ & $\begin{array}{l}\text { 5. Microcontroller programming - Atmel } \\
\text { Microcontroller } \\
\text { 6. Arduino Programming } \\
\text { 7. Building applications using } \\
\text { microcontroller, sensors and actuators. }\end{array}$ & $\begin{array}{l}\text { i. Methodology } \\
\text { ii. Selection of sensors, actuators and } \\
\text { Control system/ Modeling (software) }\end{array}$ \\
\hline $\begin{array}{l}\text { IV. De } \\
\text { problen }\end{array}$ & $\begin{array}{l}\text { 8. PLC (Programmable logic controllers) } \\
\text { basic and advanced programming } \\
\text { 9. Structured enquiry and open ended } \\
\text { experiments on PLC programming and } \\
\text { interfacing. }\end{array}$ & $\begin{array}{l}\text { i. Develop Prototype/proof of concept } \\
\text { (interfacing), IoT integration } \\
\text { ii. Programming for microcontroller or } \\
\text { PLC and IoT concept. }\end{array}$ \\
\hline $\begin{array}{l}\text { V. Build the applications using SCADA for } \\
\text { manufacturing automation. }\end{array}$ & $\begin{array}{l}\text { 10. Executing the working models through } \\
\text { integrating SCADA and PLC into the } \\
\text { manufacturing automation system. }\end{array}$ & $\begin{array}{l}\text { iii. Analysis, interpretation and } \\
\text { conclusions } \\
\text { iv. Report Writing }\end{array}$ \\
\hline
\end{tabular}




\section{B. Assessment Pattern}

Assessment for theory course is done through minor exam evaluation process, assignments and seminar activity. Graduate attributes number 1 and 2 (indicated in table 1) are measured through Manufacturing systems and automation theory course. Graduate attribute number 3,8 and 9 are measured through mini project activity. Project assessment is done through three different review processes which are evaluated through appropriate rubrics pattern. Graduate attribute number 5 is measured through laboratory course called Automation lab.

As a sample assessment pattern, delivery and evaluation process of automation lab course is being explained. Automation lab is delivered in four different approaches, namely, demonstration, exercises, structured enquiry problems and open ended problems. In demonstration section, all the concepts to be taught in laboratory courses are demonstrated by course instructor. Further, in exercise level the students are expected to solve the automation problems and execute certain well defined experiments. Taking the difficulty level one step ahead, in structured enquiry approach the students will be expected to write the programs and interface the microcontrollers and programmable logic controllers with appropriate sensors and actuators to solve the automation problem defined. Finally, in open ended approach the students will identify an industrial problem based on some initial survey, define the problem on their own, apply the automation process steps to the defined problem, write the program, interface the circuitry, analyze and interpret the results. The sample rubrics for open ended experiment are shown in table 3 of section 3.1.2. Every performance indicator in the rubrics is assessed for 10 marks in all the categories of experiments conducted in the laboratory.

The assessment results of exercises, structured enquiry and open ended experiments are shown below in sections 3.3.1, 3.1.2 and 3.1.3.

In the exercise or experiment approach, the students are expected to follow a standard approach already defined as per lab manual to carry out the exercises. Simple electro-hydraulic and electropneumatic experiments are conducted in exercise level followed by executing simple PLC ladder logic diagrams. Competency 5.1 with their indicators 5.1.1 and 5.1.2 (shown in table 3) are measured through exercise level experiments. Figure 3 shows the attainment level of entire class during conduct of exercise level in the automation laboratory.

Figure 3 clearly explains that percentage attainment of PI 5.1.1 is $77.5 \%$ and PI 5.1.2 is 63.75

$\%$. As exercise approach experiments were initial experiments for students they could not identify the modern engineering tool easily for the automation problem. Similarly, they were not able to evaluate the appropriateness of the selected tool. Students were confused between the selection of sensors, actuators and controllers during the interfacing purpose for solving automation problems. Further, at the end of all the basic exercise level they could able to select these components better.

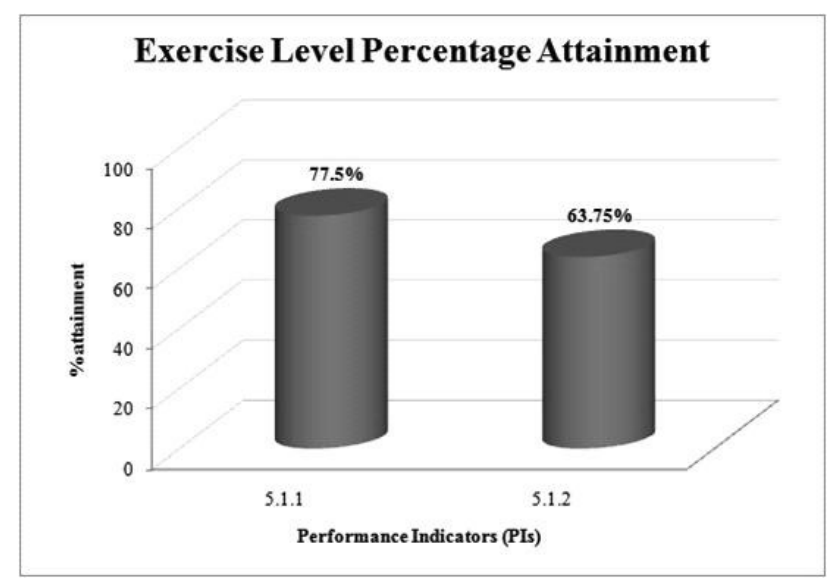

Fig.3 : Percentage attainment of PIs

5.1.1 and 5.1.2 at exercise approach

In structured enquiry approach, the students are expected to select the components on their own, write

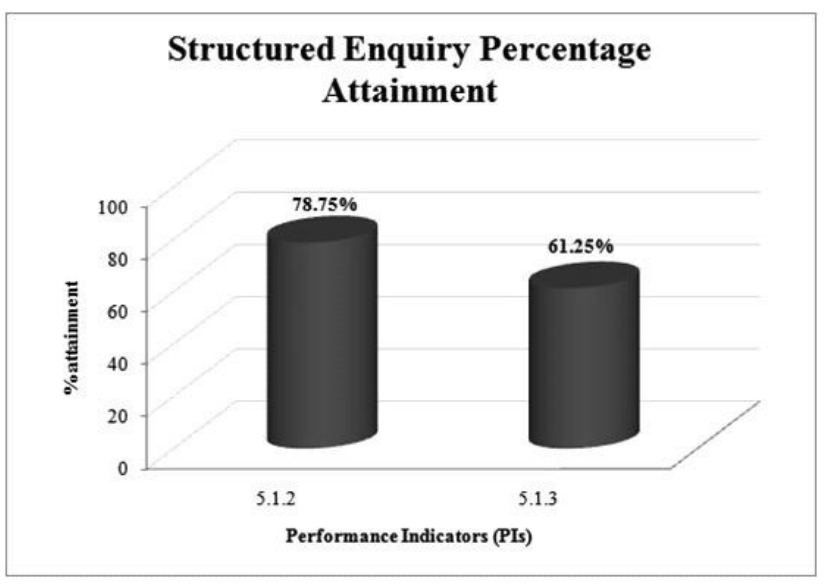

Fig.4 : Percentage attainment of PIs 5.1.2 and 5.1.3 at structured enquiry approach 
the programming part and interface the components to controllers. Competency 5.1 with their indicators 5.1.2 and 5.1.3 are measured through structured enquiry level experiments. The following diagram shows the attainment level of each student in structured enquiry approach.

It can be obsereverd from figure 4 that percentage attainment of PIs 5.1.2 and 5.1.3 at structured enquiry approach are $78.75 \%$ and $61.25 \%$ respectively. PI 5.1 .2 has increased from $63.75 \%$ to $78.75 \%$, which is a good improvement from exercise level. Here the students were able to evaulate the appropriatness of the tool selcted for automation purpose. Where as the attainment percentage of PI 5.1.3 is found to be $61.25 \%$ which is because the students lacked the analysis capacity in the starting experiemnts of structured enquiry approch. The students were further trained on the analysis part.

In open ended experiment approach, the students are expected to select an industrial problem and give the automation solution for the same using appropriate modern engineering tool. Competency 5.1 with their indicators 5.1.1, 5.1.2, 5.1.3 and 5.1.4 are measured through open ended experiments. The following diagram shows the attainment level of each student in open ended experiment approach.

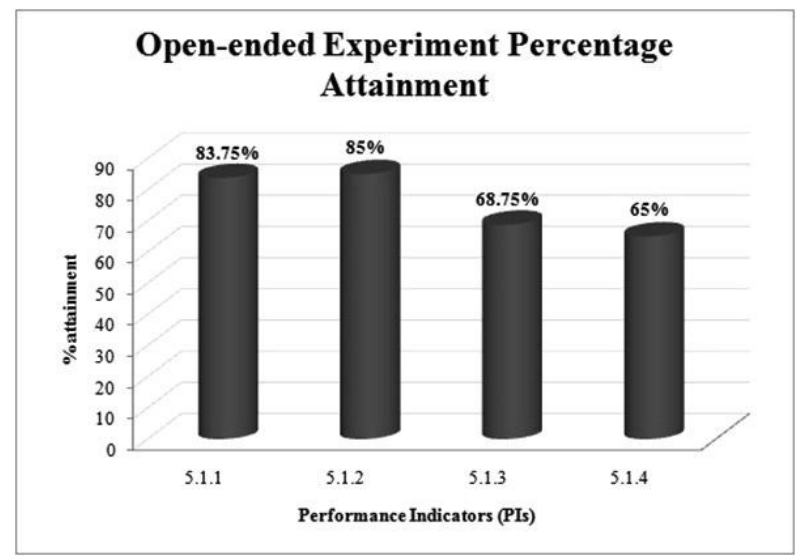

Fig.5 : Percentage attainment of PIs 5.1.1 to 5.1.4 at open ended experiment approach

From figure 5 it can be observed that percentage attainment of PIs 5.1.1 and 5.1.2 related to selection of modern engineering tool and evaluating its appropriateness is found to be good at this open ended experiment stage. Students have developed the skills of identifying the correct modern engineering tool and can evaluate its appropriateness based on the application. It can be observed in case of PIs 5.1.1 and 5.1.2 where the percentages of attainment have increased compared to exercise and structured enquiry level. Similarly, there is an observable improvement in the percentage attainment of PI 5.1 .3 from $61.25 \%$ to $68.75 \%$. The reason for improvement might be the training provided to students on analysis part during the structured enquiry level and hence the analysis level during open ended experiment is found to be satisfactory. Still there is a scope for improving the attainment of PI 5.1 .4 as the attainment is just $65 \%$. The inferences and conclusion parts were not explained in a systematic manner by the students at the end of open ended experiment and therefore the percentage attainment of PI 5.1.4 needs to be focused and improved during delivery of the laboratory course in the next cycle.

\section{Benefits and Advantages of Theme Based Curriculum Design}

- Theme based curriculum design is unified and dwells on a specific theme of recent industrial concept and application.

- There is a synergistic integration and sound combination of theory and laboratory courses along with project activity designed in the theme process which helps students to link the concepts and learn in an organized manner.

- The students are kept engaged throughout the week as they need to participate in group based activity; open ended experiments, mini project and case study based teaching learning process. This engagement will help them to think critically and analyze better in the identified theme courses.

- The learners are exposed to different software tools to enhance their knowledge and skills in the practical area of the automation theme. Some part of the time they are even exposed to self study component during the conduct of mini project activity which makes student more confident in the learning process.

- Learner and teacher both sees a continuous relationship between what is taught, what is practiced and what is being implemented throughout the concurrent process of theme based curriculum delivery.

- Learner understands the importance of societal need, industrial needs and latest trend in today's industrial scenario through problem solving 
technique during mini project activity and through technical talk from industrial personnel.

- Communication skills are also developed through continuous interaction of the students through case study activity, seminars and project review process.

- Students are benefited through proper continuity and synchronization of theory, laboratory and project activity, whereas, it's a beneficiary for faculty to measure and assess the performance of each individual student through rubrics based assessment as he/she monitors all the courses of theme based courses.

\section{Conclusions}

Theme based curriculum design concept has been developed, introduced and studied. Manufacturing automation theme was selected and systematically integrated to the existing curriculum of production management post graduate program . The methodology of theme based curriculum design starts from selecting a theme suitable to particular post graduate studies under consideration and ends with assessment criteria and review process. The study finds its importance because the theme based curriculum design creates a strong co-relationship between the theory and laboratory courses with project work carried out. Due to this synergistic integration between the courses which run parallel hand in hand throughout the semester, the students have a very good opportunity to learn the concepts in the classroom through case study approach and seminar sessions. Along with that, practicing the laboratory sessions by correlating the concepts learnt in the classroom sessions takes place effectively.

It can be observed in the assessment sections that the percentage attainment of PIs 5.1.1, 5.1.2 and 5.1.3 have increased during the open ended experiment compared from exercise level and structured enquiry approaches. Students have an opportunity to carry out mini-project tasks based on the theme selected. Therefore theme based curriculum design is most suited for professional courses like engineering studies. As these kinds of initiatives can enhance the learner's knowledge level and skill-set through appropriate teaching-learning process. This theme based curriculum can also be applied to other engineering disciplines and post graduate programs across the world to suit their requirement without affecting the existing curriculum structure.
References

[1] Dickie Carolyn and Jay Leighton, 2010, Innovation in Postgraduate Teaching: Mixed Methods to Enhance Learning and Learning, Higher Education Research and Development, Vol . 29, No . 1, 2010, pp . 29 - 43 . DOI : $10.1080 / 07294360903421376$

[2] M. J. Servan, E. Soto, J. F. Murillo, M. Sola and A. I. Perez, 2009, Problem-based learning and action research in postgraduate teaching: the interdisciplinary core, Educational Action Research, Vol.17, No.3, pp.373-389.

[3] Vinayak Kulkarni, V. N. Gaitonde and R. G. Mench, 2016, Attainment of $\mathrm{P}$ rojec $\mathrm{t}$ Management and Finance graduate Attribute (GA) for Post Graduate Program in Engineering through Course project, Journal of Engineering Education Transformations, Vol.29, No.3, pp.1-7. DOI:10.16920/jeet/2016/v29i3/85187

[4] Jane Tobbell, Victoria O'Donnell and Maria Zammit, 2010, Exploring transition to postgraduate study: shifting identities in interaction with communities, practice and participation, Journal of British Educational Research Journal, Vol.36, No.2, pp.261-278. DOI: $10.1080 / 01411920902836360$

[5] Dodge, D. T., 1995, The importance of curriculum in achieving quality child day care programs, Child Welfare: Journal of Policy, Practice and Program, Vol.74, No.6, pp.11711188.

[6] Schweinhart, L. J., \& Weikart, D. P., 1998, Why curriculum matters in early childhood education, Educational Leadership, Vol.55, No.6, pp.57-60.

[7] Melear, C. T. \& Lunsford, E., 2007, Worms cultivate our curriculum: A long-term, themebased unit, Science Activities-Projects and Curriculum Ideas in STEM Classrooms, Vol.44, No.2, pp.48-54. DOI: 10.3200/SATS.44.2.48-54

[8] Lonning, R. A., DeFranco, T. C., \& Weinland, T. P., 1998, Development of theme-based, Interdisciplinary, Integrated curriculum: A Theoretical model, School Science and Mathematics, Vol.98, No.6, pp.312-319. DOI: 10.1111/j.1949-8594.1998.tb17426.x 
[9] Halimah Tussa'diah and Kiki Nurfadillah, 2018, The Implementation of Theme Based Teaching to Improve Students' Achievement in Narrative Text, The 1st Annual International Conference on Language and Literature, $\mathrm{KnE}$ Social S c i e n c e s, p p . $352-360$. D O I : 10.18502/kss.v3i4.1946

[10] Berry, C.F., Mindes, G., \& Sweat L., 1993, Planning a theme-based curriculum: goals, themes, activities, and planning guides for $4 \mathrm{~s}$ and 5s, Glenview, IL: Good Year Books. ISBN: 06734640919780673464095
[11] Vinayak Kulkarni, Sanjay Kulkarni, Jangali G. Satish, V.N. Gaitonde, 2017, Attainment of major competencies of program-specific outcome in industrial engineering and simulation lab through open - ende $\mathrm{d}$ e xperiment, International Journal of Continuing Engineering Education and Life-Long Learning, Vol 27, N o. 3,p p . 183 - 197 . D O I : 10.1504/IJCEELL.2017.084840 